\title{
Effectiveness of drotaverine hydrochloride in progression of labour
}

\author{
Meena Thapa, Rachana Saha, Amita Pradhan, Sweety Shrestha \\ Kathmandu Medical College Teaching Hospital (KMCTH)
}

\begin{abstract}
Aim: This study was done to compare the effectiveness of drotaverine hydrochloride and valethamate bromide in shortening duration of labour.

Methods: It is a hospital based prospective study, carried out in the department of Obstetrics \& Gynaecology at Kathmandu Medical College Teaching Hospital (KMCTH), Sinamangal from $1^{\text {st }}$ June to $31^{\text {st }}$ August 2005. 99 patients, who were in active labour, were taken into the study. Out of which 50 were in drotaverine group (Group 1) who had received $40 \mathrm{mg}$ of drotaverine hydrochloride intramuscularly at 3 to $5 \mathrm{~cm}$ dilatation of the cervix. Rest of 49 patients were in valethamate bromide group (Group 2). They received 3 doses of $8 \mathrm{mg}$ valethamate bromide and $20 \mathrm{mg}$ hyoscin butyl bromide intravenously half an hour interval.

Result: The injection-delivery interval was studied in both Groups. The duration of injection-delivery interval was found to be almost equal in primigravidae of both Groups $(p=0.72)$. But in multigravidae interval was significantly shorter in drotaverine Group $(p=0.03)$.

Conclusion: Both drotaverine and valethamate bromide are equally effective in shortening duration labour in primigravidae, where as drotaverine is more effective in multigravidae in accelerating labour.

Keywords: Drotaverine, Valethamate bromide, cervical dilatation, labour acceleration
\end{abstract}

\section{Introduction}

Labour is the process in which contractions of gravid uterus expels the fetus, from womb to the exterior through the vagina. Active management of labour is being practiced into clinical practice by obstetrician all over the world. Its aim is to reduce the duration of labour. ${ }^{1}$

Smooth muscle relaxants are well accepted in progression of labour. Apart from uterine contraction cervical dilatation is an important factor, which determines the duration of labour. It is the resistant of all driving forces of uterine contraction against passive tissue resistance. Smooth muscle relaxants inhibit impulses in the form of spasm that impairs the effective cervical dilatation. Various agents have been used to combat cervical muscle spasm. ${ }^{1}$

Recently, drotaverine hydrochloride has been used as cervical relaxant. It is derivative of benzyl isoquinolone, which has got anti-phosphodiasterare action thus increases the intracellular level of adenosine monophosphate (cAMP). It is safe during pregnancy. So it is rapidly emerging as an excellent drug to hasten cervical dilatation. Valethamate bromide is an ester which has got spasmolytic action by virtue of its anticholenergic and musculotropic action. It also relieves the spasm of smooth muscle of the cervix facilitating cervical dilatation. ${ }^{2}$

\section{Objective}

The objective of this study was to compare the efficacy of drotaverine hydrochloride with valethamate bromide in shortening the duration of labour.

\section{Method}

It was a comparative, prospective, hospital based study carried out at Kathmandu Medical College Teaching Hospital, Kathmandu, over the period of 3 months from $1^{\text {st }}$ June to $31^{\text {st }}$ August 2005.

\section{Correspondence}

Dr. Meena Thapa, MD.

Lecturer, Dept. of Obs \& Gyn KMCTH, Tel.9851060052 (M) 4364917 (Res.); Email rabi@kmc.edu.np 
Total of 99 labouring patients were taken into the study. Both primi and multi-gravidae, fulfilling following criteria were included in the study. A) Term pregnancy with cephalic presentation B) Singleton pregnancy C) Those who were in active phase of labour with cervical dilatation of 3 to $5 \mathrm{~cm}$ with partially effaced cervix and having regular uterine contraction of 2 to 3 contraction per 10 minutes, with or without oxtocin infusion.
Women with malpresentation, multifetal gestation and previous history of cervical surgery were excluded from this study.

In both Groups of patients duration of $1^{\text {st }}$ dose of injection and delivery was recorded. It was analysed and compared between 2 Groups.

Table I. Injection - delivery interval in Group I (Drotaverine Group)

\begin{tabular}{|c|c|c|c|c|}
\hline \multirow{2}{*}{$\begin{array}{l}\text { Cervical dilatation } \\
\text { at injection }\end{array}$} & \multirow{2}{*}{$\begin{array}{l}\text { No. of cases } \\
\qquad(\mathrm{n}=50)\end{array}$} & \multicolumn{2}{|c|}{$\begin{array}{l}\text { Mean duration of injection - delivery interval } \\
\text { (in minute) }\end{array}$} & \multirow{2}{*}{ p-value } \\
\hline & & Primigravida $(\mathrm{n}=31)$ & Multigravida $(n=19)$ & \\
\hline $3 \mathrm{~cm}$ & $\begin{array}{c}14 \\
(25-385)\end{array}$ & $\begin{array}{l}231.7 \pm 92.5 \mathrm{~min} \\
(130-310 \mathrm{~min})\end{array}$ & $193 \pm 101.4 \mathrm{~min}$ & \\
\hline $4 \mathrm{~cm}$ & $\begin{array}{c}22 \\
(31-360 \mathrm{~min})\end{array}$ & $\begin{array}{l}189.8 \pm 92.7 \mathrm{~min} \\
(45-265 \mathrm{~min})\end{array}$ & $121 \pm 71.3 \mathrm{~min}$ & \\
\hline $5 \mathrm{~cm}$ & $\begin{array}{c}14 \\
(75-256 \mathrm{~min})\end{array}$ & $\begin{array}{l}163.22 \pm 53.7 \mathrm{~min} \\
(80-135 \mathrm{~min})\end{array}$ & $103 \pm 24.3 \mathrm{~min}$ & \\
\hline $\begin{array}{l}\text { Overall mean duration } \\
\text { of injection delivery } \\
\text { interval }\end{array}$ & 50 & $\begin{array}{c}196.9 \pm 85.4 \mathrm{~min} \\
(25-385 \mathrm{~min})\end{array}$ & $\begin{array}{c}127.6 \pm 70.8 \mathrm{~min} \\
(45-310 \mathrm{~min})\end{array}$ & 0.005 \\
\hline \multicolumn{5}{|c|}{$\begin{array}{l}\text { Out of } 50 \text { cases in Group } 1,31 \text { cases were primigravidae and } 19 \text { were multigravidae. The average duration of injection } \\
\text { delivery interval in primigravidae was } 196.9 \pm 85.4 \text { min where as in multigravidae it was only } 127.6 \pm 70.8 \text { min. In this } \\
\text { study mean duration of injection - delivery interval was found significantly shorter in multigravidae than primigravidae } \\
(p=0.005) \text {. }\end{array}$} \\
\hline \multirow{2}{*}{$\begin{array}{l}\text { ervical dilatation at } 1^{\text {st }} \\
\text { dose of injection }\end{array}$} & \multirow{2}{*}{$\begin{array}{l}\text { No. of cases } \\
\qquad(\mathrm{n}=50)\end{array}$} & \multicolumn{2}{|c|}{$\begin{array}{l}\text { Mean duration of injection - delivery interval } \\
\text { (in minute) }\end{array}$} & \multirow{2}{*}{ p-value } \\
\hline & & Primigravida $(\mathrm{n}=27)$ & Multigravida $(n=22)$ & \\
\hline $3 \mathrm{~cm}$ & 21 & $\begin{array}{l}260.2 \pm 115.4 \mathrm{~min} \\
(157-450 \mathrm{~min})\end{array}$ & $\begin{array}{l}255 \pm 39.3 \mathrm{~min} \\
(200-290 \mathrm{~min})\end{array}$ & \\
\hline $4 \mathrm{~cm}$ & 17 & $\begin{array}{l}194.7 \pm 104.6 \mathrm{~min} \\
(70-420 \mathrm{~min})\end{array}$ & $\begin{array}{l}210.3 \pm 99.4 \mathrm{~min} \\
(60-330 \mathrm{~min})\end{array}$ & \\
\hline $5 \mathrm{~cm}$ & $\begin{array}{c}11 \\
(70-180 \mathrm{~min})\end{array}$ & $\begin{array}{l}124.1 \pm 40 \mathrm{~min} \\
(50-188 \mathrm{~min})\end{array}$ & $120.1 \pm 48.1 \mathrm{~min}$ & \\
\hline $\begin{array}{l}\text { Overall mean duration } \\
\text { of injection delivery } \\
\text { interval }\end{array}$ & 49 & $188.1 \pm 10.3 \mathrm{~min}$ & $182.7 \pm 89.4 \mathrm{~min}$ & 0.84 \\
\hline
\end{tabular}

Out of 49 patients, 27 patients were primigravidae and 22 were multigravidae. In most of the patients, $1^{\text {st }}$ dose of injection was given at 3 to $4 \mathrm{~cm}$ cervical dilatation. Over all mean duration of injection-delivery interval in primi and multigravidae was $188.1 \pm 10.3$ min and $182.7 \pm 89.4$ min which is statistically comparable. 
Table 3. Comparison between Injection - Delivery Interval of Group I and Group 2

\begin{tabular}{lccccc}
\hline & \multicolumn{2}{c}{ Group 1 } & \multicolumn{2}{c}{ Group 2 } & \multirow{2}{*}{ p-value } \\
\cline { 2 - 5 } & No. of cases & Mean Duration & No. of cases & Mean Duration & \\
\hline Primi gravidae & 31 & $196.9 \mathrm{~min}$ & 27 & $188.1 \mathrm{~min}$ & $0.72(\mathrm{t}=.35)$ \\
Multi gravidae & 19 & $127 \mathrm{~min}$ & 22 & $182.7 \mathrm{~min}$ & $0.03(\mathrm{t}=2.1)$ \\
\hline
\end{tabular}

The mean duration of injection-delivery interval in both Groups, was found to be comparable in primigravidae $(p=0.72)$. But mean duration in multigravadae was significantly shorter $(p=0.03)$ in Drotaverine Group (Group 1). There was a case of cervical tear in both the groups.

\section{Result}

Total of 99 patients were enrolled in this study. Out of which 50 patients were in Group 1 (Drotaverine Group). Among 50 patients, 31 patients were primigravidae and 19 were multigravidae (62\% and $38 \%$ respectively).

49 patients were enrolled in Group 2 (Valethamate Group). Out of which 27 were primigravidae and 22 were multigravidae. ( $55 \%$ and $45 \%$ respectively).

The mean age of patients of Group 1 and 2 were 22.8 years and 23.3 years respectively.

The mean gestational age of patients of Group 1 and 2, were 39 weeks and 39.8 weeks respectively.

\section{Discussion}

This was a randomized study to compare the efficacy of drotaverine and valethamate bromide in shortening duration of labour. Drotaverine causes smooth muscle relaxation. The beneficial effect is also seen in spastic dystocia of the cervix. ${ }^{1}$ Valethamate bromide is an ester and is a potent and rapidly acting anticholenergic spasmolytic agent. It shortens the labour by rapidly dilating cervix.

In this study the injection delivery interval was studied in both Groups. The interval was found to be shorter in multigravidae in Group 1 patients $(\mathrm{p}=0.72)$. But in primigravidae both drugs have got similar efficacy in accelerating active stage of labour $(p=0.03)$. Efficacy of shortening active labour had been studied in studied 300 cases of primigravidae divided into 3 (each consisting 100 cases). Group 1 had received Drotaverine, Group 2 had received Valethamate bromide and Group 3 only Oxytocin infusion. Efficacy of shortening active labour was statistically similar with Drotaverine and Valethamate bromide. ${ }^{2}$

But according to Kaur $\mathrm{D}^{3}$ et al, Mishra SL ${ }^{4}$ et al, Sharma JB ' ${ }^{1}$ et al, drotaverine is more effective in shortening duration of labour than valethamate bromide

Gupta K et al did 535 cases of delivery with Drotaverine.
They conclude that Drotaverine is effective in reducing the duration of labour by hastening cervical dilatation. It is more effective when membrane has been ruptured. It is also found that Drotaverine does not increase in the incidence of operative delivery. ${ }^{5}$

\section{Conclusion}

Both Drotaverine and Valethamate bromide are equally effective in shortening duration labour in primigravidae. But in multigravidae, Drotaverine dilates the cervix more rapidly than Valethamate.

\section{Acknowledgements}

I am thankful to our patients without whom this study would not have been possible; I am also thankful to all faculty members and staffs of department of Obstetrics and Gynaecology of the KMCTH for preparing this study.

\section{References}

1. Sharma JB, Pundir P, Kumar A, Murthy NS. Drotaverine hydrochloride Vs Valethamate bromide in acceleration of labour. International $\mathrm{J}$ Gynaecol Obstet Ind 2001; 4;(6),

2. Sankar M, Goswami B, Biswas B. A study of Drotaverine on duration of first stage of labour. J Int. Medical Sciences Academy 2000; 13;(4):256257,

3. Kaur D, Kaur Ravinder. Comparision of Drotaverine and epidosin in first stage of labour. J Obstet Gynaecol Ind 2003; 53;(5):449-452,

4. Mishra SL, Toshniwal A, Banerjee R. Effect of Drotaverine on cervical dilatation: A comparative study with epidesin. J Obstet Gynaecol Ind 2002; 52 (3): 76-79.

5. Gupta K, Mukharjee K, Chowdhary B. Effect of Drotaverine on the first stage of labour. Obs \& Gynae Today 2003; 8(3): 